\title{
English Language Teaching Policy at a Russian University
}

\author{
Svetlana Pitina \\ Chelyabinsk State University, Chelyabinsk, Russian Federation
}

\begin{abstract}
The language policy and EFL (English as a Foreign Language) curriculum in Russian universities are standardized, but changes are possible to meet local needs and overcome cultural barriers. The paper is a comparative study of teaching and learning English in different cultural environment at Chelyabinsk State University in the South Urals and its branch in Kostanay, Kazakhstan. The analysis is based upon the 10 teachers' and 40 students' interviews and the author's teaching experience at Chelyabinsk State University and its Kostanay branch.
\end{abstract}

Keywords: language policy, English teaching and learning, problems, discourse teaching

\section{Introduction}

In Russia, language policy has manifested itself in various aspects of social life.

It includes the study and knowledge of Russian as the official language of the country, the study and knowledge of a foreign language at the elementary, high school, and the university. Moreover, all immigrants who want to work on the permanent or temporary basis should take an exam in Russian at special certified centers.

There are only two branches of Russian universities in Kazakhstan, a country with a large percentage of the Russian speaking population even among the title Kazakh nation. It explains the popularity of the Kostanay branch of Chelyabinsk State University among the young people leaving on the border with the Russian Federation. Bilingual Kostanay and Kazakhstan in general are interested in learning English, which is in accordance with the state policy of integration. Kazakhstan language situation is quickly changing to be described as trilingual: Kazakh is for everyday usage and career; Russian is for immigration, better work opportunities, and everyday communication; English is for prestigious jobs, promotion, and perspective of immigration.

The knowledge of Russian is assessed during the Universal State Exam taken by all high school leavers. The results are taken into account at the entrance exams by all Russian higher educational establishments. The required minimum of points is rather low, 36 out of 100 in 2015 for higher education applicants and only 24 points for school leavers with the certificate.

The requirements for those who take an exam in a foreign language are even lower than in Russian final assessment. It is only 22 points out of 100 in 2015. Such pessimistic statistics result in many problems faced by EFL teachers at schools and colleges.

This study intends to answer the following research questions: (1) How to teach EFL if students possess different, often rather poor, knowledge of Russian and English? (2) Should teachers follow a standard curriculum in EFL teaching or approach the teaching process creatively? 


\section{Modern EFL Students}

University students can choose a foreign language to study for four semesters (two academic years), but in practice the choice is limited to English in many universities. The selection of English is justified by its global status in modern science, by the growing opportunities to study abroad, by the recognition of Russian diplomas in many countries, and by teaching in English in Russian universities.

Language schools and faculties offer a wider choice of languages; however, English is included in all bachelor and master programs. This paper is limited to the analysis of English majors in Chelyabinsk State University and the author's 30 years of EFL teaching experience.

Chelyabinsk State University offers several bachelor and master programs in EFL at Linguistics and Translation and at Historical and Philological Faculties. Students can specialize in cross-cultural communication, translation, teaching English, and English literature.

The vast majority of students enter higher establishments after finishing high school without a clear idea about their career, following the advice of parents, friends, or teachers. Their expectations do not coincide with what they have to learn; their cross-cultural competence fails to meet the university demands because their background knowledge is insufficient for independent university studies.

There are three groups of the first year students in Chelyabinsk State University. Students' streamlining is undertaken through tests during the first week of their studies.

The first group $(20 \%)$ consists of the students with the intermediate and upper intermediate level of English. It includes special language high school leavers, diligent students with 75 and more points for the Universal State Exam in English.

Intermediate language and cross-cultural competences allow them to master the university curriculum independently. They read books by English authors in the original, watch English movies without subtitles. Their listening, speaking, reading, and writing skills are enough to understand language theory and its practical implementation. Such students study on the budget level, get grants, graduate with honors, and continue to study for the master degree.

The second group (50-55\%) includes the students with the low intermediate English language level. They can be subdivided into two subgroups: (1) with stimuli to develop language skills, cross-cultural competence, demonstrate steady progress; (2) without motivation to improve their English level. Representatives of the latter group are often expelled after the first or second year.

The last group (30-25\%) is the hardest for EFL teachers to work with. Only a few of them manage to graduate and very seldom such students work as English teachers or interpreters after graduation.

All the three groups are open, if there are two or more academic groups, students are divided according to the initial English level into the "beginners" and "followers". Teachers can transfer students to an upper level class after exams.

Many Kostanay branch students are bilingual which makes it easier for them to learn English. They are more mobile and ready to change the place of living. Many Kostanay EFL students want to find a job in Russia and abroad.

The objectives of the EFL teaching of rather diverse classes are as follows: (1) leveling English competence in reading, writing, speaking, and listening in weak groups; (2) improving students' language competence in all groups; (3) preparing students for professional activity as English teachers, interpreters, or 
translators; (4) assisting in acculturation in a multicultural environment.

\section{Method}

This study is a cross-cultural approach to analyze teachers' and students' perception of the language teaching policy in Chelyabinsk State University and in its Kostanay branch in Kazakhstan. The target of the interview questions is to gather information about: (1) the teachers' perception of the university policy on the EFL teaching; (2) the students' response to the university policy on the EFL learning; (3) the problems in English teaching and learning.

\section{Data Collection}

Data collection consisted in the content analysis of 10 teachers' and 40 students' interviews on EFL teaching and learning, classroom observation, and educational document analysis. The interviewees were five Kostanay and five Chelyabinsk English teachers, 12 Kostanay second year students majoring in Translation, 11 Kostanay and nine Chelyabinsk second year students majoring in English, 12 Chelyabinsk second year students majoring in English Teaching. Four classroom observations lasted 135 minutes each with a 5 minute break time after 45 minutes verified the interviews.

\section{Results}

Results of the study help understand the difficulties encountered by English teachers and English learners when using standard curriculum.

\section{Teachers' Perception of EFL Teaching}

Both Chelyabinsk and Kostanay teachers acknowledged the importance of intensive methods implementation in English teaching. All teachers stressed the necessity of refreshment courses for teachers run by the native speakers. Only four out of five Chelyabinsk State University teachers studied in the English speaking countries once or several times. Kostanay teachers graduated from the local universities and had no chance to study abroad.

Chelyabinsk teachers delivered lectures on language theory and conducted workshops and tutorials in English, Kostanay teachers conduct practical classes only.

All 10 teachers agreed that teaching writing, reading, listening, and speaking as separate skill was the most efficient way in mastering the subject during the first two years at the university.

Chelyabinsk teachers expressed the universal opinion that discourse approach to teaching English was the most successful for all students. The author's department has been practicing this approach for about 10 years, when the university began to participate in the Oxford-Russia project for the teachers of English. The project concentrates on teaching modern British literature, free ordering and shipping of the necessary amount of copies of 24 modern British novels to participating universities, writing commentaries with annotations with students after the novels discussions, correcting students' essays on the novels they are reading, publishing the 8 issues of the Footpath journal, participating in the annual September international seminar "Contemporary English Literature in Russian Universities" in Perm State University organized by professors Karen Hewitt and Boris Proskurnin, May seminars for English teachers in Oxford and many other teachers and students involving activities. The project is a great success among about 100 Russian universities because it helps overcome cultural difficulties and misunderstanding in language teaching and learning. In the editorial article "On the Literary Dangers of Searching for Russians" in Footpath eight, Karen Hewitt justly pointed out: 
I am suggesting that the best way of dealing with confusions about a different culture is to identify how to read each novel. Each reader asks himself or herself: What is the author trying to tell me? How do I know? In each case 4 the answers will be different and will require careful reading and searching in the text, but the process of finding out is itself a guide to the attitudes of the author. It protects us from seeing everything that happens as somehow typical of "the English" or "the British", just as finding out how to read "The Kreutzer Sonata" helps us to understand Tolstoy and distinguish his story from "typical Russian attitudes". (Hewitt, 2014, p. 9)

Discourse teaching approach avoids simplification and stereotypes in language and cultural diversity understanding, teaches creative thinking interpretation and writing. Discourse reading teaching should be enjoyable not boring (Pitina, 2013). The contemporary British novels are read by Chelyabinsk bachelor students in class and as a part of extensive home reading subject. The first year students enjoy reading Magpie by Jill Dawson, About a Boy by Nick Hornby, The House in Norham Gardens by Penelope Lively, second years like to analyze Black Swan Green by David Mitchell, Portobello by Ruth Rendell, third and fourth year student are eloquent enough to discuss A History of the World in 10 1/2 Chapters by Julian Barnes, provocative for a Russian reader Master Georgie by Beryl Bainbridge, Morality Play by Barry Unsworth, a beautiful panorama of Waterland by Graham Swift, very actual and ironical White Teeth by Zadie Smith, a powerful Atonement by Ian McEwan, and many other deserving serious study contemporary British novels. Teachers and students write commentaries on the novels with annotations prepared with a grant from the Oxford Russia Fund (Hewitt, 2007, 2008a, 2008b, 2008c, 2010, 2011a, and many others). Not many fluent English speaking students manage to understand the 12 one-word title chapters of Adam Thorpe's brilliant Ulverton. Each story is related to the next one in many ways; it is never explicit, leaving the searching reader the excitement of finding the details which seemed obscure in a previous chapter (Hewitt, 2011b).

All the interviewed teachers and students from Chelyabinsk State University agreed that discourse teaching and learning was highly effective, took a lot of effort, and was very time consuming but rewarding.

There is a tough competition among Chelyabinsk teachers to be chosen as the seminar participants and use its results in class discourse teaching.

However, Kostanay teachers participated in the project only once and refused to continue because of many other things to do, and preferring the traditional approach in English teaching, using ready-made commentaries on the books and text created by 19th century and early 20th century authors, high and average quality literary works written in English, in English never spoken or written nowadays.

\section{Teaching Challenges}

All the interviewed teachers responded that the most difficult task was to teach students with different English proficiency in one class. The classes are large in Kostanay, consisting 15 or 18 students with different level of English proficiency. It is impossible to ask all the students during one lesson and to pay attention to the mistakes they make.

The teachers stressed that small class teaching was far more effective, but contradicting the standard student-teacher ratio of 15 to 1 . Several years ago, an average EFL academic group in Russian universities used to consist of not more than 10-12 students.

Routine paper work and constant administrative assessment prevent teachers from the teaching process and individual work with the best and the weakest students.

A teacher N, 35 years of university teaching experience, remarked:

When I started teaching in Chelyabinsk State University, I had to fill in only two documents: my individual plan of 
work for the academic year and lesson plans. In 2015, I had to write and rewrite all the subject programs according to the constantly changing State Standard for 4 academic groups without a guarantee that no innovations should be added! (N, personal communication, May 20, 2015)

Teaching writing proved to be the most difficult skill to implement because it requires integration of various skills, rich thesaurus, and cultural literacy.

All interviewees complained that the number of teaching hours in the classroom decreased every year. It is difficult, if impossible, to improve students' language competence when there are only eight or six hours per week to practice!

Generation gap is another challenge for English teachers. The average age of university professors and associate professors is over 55 and average salary is low, but requirements are high. Thanks to the present economical situation, high unemployment level, many talented university graduates want to teach and conduct research at universities. Unfortunately, a middle aged English teacher is a rara avis at Russian universities. Analogous situation is in Kazakhstan, which leaves hope for overcoming many of the challenges in higher education in general and English teaching in particular.

\section{Students' Perception of EFL Learning}

All 40 students wrote about the importance of learning English, but only $50 \%$ stated that they would use it in their professional activity. All 12 students who chose English Teaching major subject were not disappointed in the choice of their future occupation (The average entrance exam result in English in this group is 75 points).

The interviewed students preferred expensive authentic English textbooks to the cheaper officially recommended textbooks written not by the native English speakers. The Educational Standard and assessment commissions demand that all textbooks should be published recently (Textbooks issued in 2010 will not be taken into account in 2015, whatever the quality and academic recognition). Bureaucratic approach to EFL textbooks creates additional problems for students.

$60 \%$ of Chelyabinsk and $50 \%$ of Kostanay students connected their EFL learning with the quality of EFL teaching:

If all teachers knew and taught English like Professor X, I would never skip classes! (Y, personal communication, May 21, 2015)

$80 \%$ of the interviewed students agreed that writing skills training tasks were the most boring and difficult. Video watching and discussion were among the most popular assignments. Equally popular were translation tasks from English into Russian, but not from Russian into English, reports and presentations, case study, discourse reading and interpretation, and game learning (We must not forget that 18 year old second year students were interviewed!).

Assessment results are very important for Kostanay students. Chelyabinsk second year students were more interested in the quality of teaching. They gave a larger number of correct answers to the questions from the previously studied subjects than Kostanay students.

Only Chelyabinsk students answered that they would complain and demand a new teacher if they did not improve their English level.

Kostanay students thought that their complaints would only lead to failures at exams and credits. This "passive" attitude to EFL learning problems is deeply rooted in the national identity and values. The elders, the authority, in our case the teachers, should be obeyed whatever they say, in our case however they teach. 


\section{Policy Recommendations}

The study offers different approaches to English teaching and learning in different cultural environment.

The Ministry of Education and Science should provide several options for teachers instead of the unified program. Creative approaches to language learning should be encouraged.

Teachers' professional efficiency should be annually assessed by independent experts and by the students. Conditions for teachers' refreshment training should be created.

Authentic textbooks should be accessible and not judged by the time of publishing.

\section{Conclusion}

Language policy reflects the state of society. Balanced language policy simplifies society integration, cultural tolerance, and cross cultural communication. Foreign language teaching and learning policy is a part of the language policy which is not ideal but open to discussions and changes.

\section{References}

Hewitt, K. (2014). On the literary dangers of searching for Russians. Footpath: A Journal of Contemporary British Literature in Russian Universities, 8(3), 6-12.

Pitina, S. (2013). Enjoyable reading. Footpath: A Journal of Contemporary British Literature in Russian Universities, 7, 8-12.

Hewitt, K. (Ed.). (2007). White Teeth by Zadie Smith: A commentary with annotations. Perm: Publ. PSU.

Hewitt, K. (Ed.). (2008a). Magpie by Jill Dawson: A commentary with annotations. Perm: Publ. PSU.

Hewitt, K. (Ed.). (2008b). Master Georgie by Beryl Bainbridge: A commentary with annotations. Perm: Publ. PSU.

Hewitt, K. (Ed.). (2008c). Morality Play by Barry Unswotrh: A commentary with annotations. Perm: Publ. PSU.

Hewitt, K. (Ed.). (2010). Black Swan Green by David Mitchell: A commentary with Annotations. Perm: Publ. PSU.

Hewitt, K. (Ed.). (2011a). Portobello by Ruth Rendell: A commentary with annotations. Perm: Publ. PSU.

Hewitt, K. (Ed.). (2011b). Ulverton by Adam Thorpe: A commentary with annotations. Perm: Publ. PSU. 